\title{
ORGANIZATIONAL COMPLEXITY OF CORAL FAUNAS BEFORE AND AFTER THE LATE ORDOVICIAN EXTINCTION EVENT
}

ELIAS*, Robert J., Department of Geological Sciences, University of Manitoba, Winnipeg, MB

R3T 2N2, Canada; YOUNG, Graham A., Manitoba Museum of Man and Nature, 190 Rupert Avenue, Winnipeg, MB R3B 0N2, Canada

In the North American continental interior, typical Late Ordovician coral faunas disappeared during an extinction event at the end of Richmondian time. Pre-extinction faunas belong to the Red River-Stony Mountain and Richmond provinces. The post-extinction Edgewood fauna, of latest Ordovician (Gamachian) to earliest Silurian (early Rhuddanian) age, occurs in the Edgewood Province of the eastcentral United States. A similar but poorly known fauna is present in the Williston Basin. Typical Early Silurian recovery faunas appeared widely in the late Rhuddanian and diversified through the Llandovery. The above faunas and provinces have been recognized on the basis of their distinctive taxonomic compositions. Here, we examine and compare their organizational complexities in terms of ecologic tolerances of taxa and presence of associations of environmentally specialized taxa.

Distinct ecologic associations of taxa occur in the pre-extinction, typical Late Ordovician coral faunas. For example, in the Red River-Stony Mountain Province there are two associations of solitary rugosans with differing, but to a certain extent overlapping, environmental preferences. Grewingkia, Lobocorallium, and Deiracorallium favored deeper water, higher energy, open-marine environments, whereas Salvadorea and Bighornia preferred shallower water, lower energy environments and tolerated somewhat restricted conditions. The relative abundances of corals belonging to these two associations record temporal changes and geographic differences in environmental conditions. In the Richmond Province, biostromes were formed by various associations of colonial corals. Some are dominated by Favistina or Cyathophylloides (colonial rugosans), with one or more tabulates such as Calapoecia, tetradiids, and Foerstephyllum. Others are dominated by Foerstephyllum, with tetradiids and Calapoecia, or were formed by tetradiids (possibly not corals), which had the greatest tolerance for restricted conditions. The solitary rugosans Grewingkia and Streptelasma tend to be absent or rare in these biostromes, but are common in many other environmental settings. Grewingkia inhabited soft substrates, whereas Streptelasma was epifaunal on stabilized substrates during periods of non-deposition.

The post-extinction Edgewood coral fauna is a single association of species. There are no distinct, specialized, recurring associations in particular lithofacies or geographic areas within the Edgewood Province. The fauna is strongly dominated by Streptelasma subregulare, a solitary rugosan. The most abundant tabulates are Paleofavosites subelongus, Propora thebesensis, and Halysites alexandricus. These four species are the most widely distributed corals in the province. Diversity generally increases along an environmental gradient from restricted, low-energy, relatively turbid conditions, to open, highenergy, clear-water conditions; diversity is low in the nearshore and farthest offshore settings. Where only one species is present, it is almost always $S$. subregulare. With increasing diversity, the three common tabulate species are usually added, followed by other species of rugosans and tabulates. Variability in diversity typically resulted simply from progressive addition or subtraction, in a particular order, of stenotopic species in a fauna dominated by eurytopic species. Coral abundance can be high in any environment, and $S$. subregulare is usually the most common species. Corals that maintained dominance throughout the province were opportunistic ecologic generalists.

Distinct ecologic associations of coral taxa appeared again in typical Early Silurian recovery faunas. For example, in the Rhuddanian of Manitoulin Island favositid tabulates and solitary rugosans occur in level-bottom environments. Various types of bioherms are present, including favositid-dominated and colonial rugosan-dominated. Some of the latter have different associations of taxa on basin- and shorefacing sides of the bioherm.

The Late Ordovician extinction event resulted in an ecologic as well as taxonomic reorganization of coral faunas in the North American continental interior. The simply organized post-extinction fauna occurs temporally between more complexly organized pre-extinction faunas and recovery faunas. 